\title{
Moroccan Arabic version of the Quality of Life Inventory in Epilepsy (QOLIE-31): translation, cultural adaptation and psychometric validation
}

Maryam Alami Merrouni, ${ }^{1}$ Abdelkrim Janati Idrissi, ${ }^{3}$ Abdelazizi Lamkaddem, ${ }^{3}$ Filankembo Kava A.C. ${ }^{2}$ Samira El Fakir ${ }^{2}$ and Zouhayr Souirti ${ }^{1,3}$

${ }^{1}$ Department of Neurology, Hassan-II Teaching Hospital, Fez, Morocco. ${ }^{2}$ Epidemiology and Clinical Research Laboratory, Faculty of Medicine and Pharmacy, Sidi Mohammed Ben Abdellah, University, Fez, Morocco. ${ }^{3}$ Clinical Neurosciences Laboratory, Faculty of Medicine and Pharmacy, Sidi Mohammed Ben Abdellah, University, Fez, Morocco (Correspondence to: A.J. Idrissi: janat318ia@gmail.com).

\begin{abstract}
Background: There is currently a growing concern to conduct health-related quality of life (HRQOL) studies among people with epilepsy in low- and middle-income countries, as most data have been derived from high-income countries in North America and Europe.

Aims: To translate, adapt and validate the Moroccan Arabic version of the QOL Inventory in Epilepsy-31 (MA-QOLIE-31) to evaluate HRQOL predictors in the Moroccan population with epilepsy.

Methods: Adaptation and validation of QOLIE-31 were performed in July 2018 among 118 patients with epilepsy in the Fez-Meknes region. The test was translated, adapted and validated into Arabic according to the Streiner \& Norman recommendations. Acceptability, reliability, central tendency and validity of the QOLIE-31 were assessed.

Results: The acceptability and reproducibility were satisfactory and the internal consistency was strong (Cronbach $\alpha=$ 0.993). The mean (standard deviation) global score of QOL in the MA-QOLIE-31 was 68 (22.16). The scores in the subscales were 51 (36.88) for seizures worry, 48.86 (25.44) for overall QOL, 45.60 (26.73) for well-being, 41.28 (25.37) for energy and fatigue, 47.55 (28.33) for cognitive function, 66.83 (39.49) for medication effects and 52.44 (30.26) for social functioning.

Conclusions: The global score of QOL in Moroccan patients with epilepsy is similar to that in patients in low and middle-income countries. MA-QOLIE-31 will facilitate further studies in HRQOL in Morocco and Arabic-speaking countries. Keywords: cultural adaptation, epilepsy, Morocco, quality of life, QOLIE-31.

Citation: Merrouni MA; Idrissi AJ; Lamkaddem A; Kava ACF; El Fakir S; Sourti Z. Moroccan Arabic version of the Quality of Life Inventory in Epilepsy (QOLIE-31): translation, cultural adaptation and psychometric validation. East Mediterr Health J. 2021;27(3):293-299 https://doi.org/10.26719/2021.27.3.293 Received: 29/10/19; accepted: 01/04/20

Copyright $@$ World Health Organization (WHO) 2021. Open Access. Some rights reserved. This work is available under the CC BY-NC-SA 3.0 IGO license (https://creativecommons.org/licenses/by-nc-sa/3.0/igo)
\end{abstract}

\section{Introduction}

There is currently a growing concern to conduct health-related quality of life (HRQOL) studies among people with epilepsy in low- and middle-income countries. Most data have been derived from high-income countries in North America and Europe (1). People with epilepsy often have a concern about seizure recurrence, even in those with few or no current seizures. However, the medical care of people with epilepsy should not be limited to stopping or reducing seizures, but should also focus on QOL, as the disorder can have a major impact on that. Epilepsy has physical, psychological and cognitive consequences. Furthermore, adults with epilepsy have many social concerns $(2-4)$, like restrictions in driving and professional constraints (5-7).

There are almost no studies on epilepsy incidence and prevalence in Morocco. According to a study performed in Casablanca in 1998, 1.1\% of the population was affected by epilepsy. There is poor knowledge about epilepsy among teachers in Morocco, and this unawareness negatively affects teachers' attitudes towards people with epilepsy (8).

The internationally used Quality of Life in Epilepsy Inventory with 31 items (QOLIE-31), was originally developed and validated in the United States of America (USA) (9) and has been shown to respond to change $(10,11)$. In a broad intercultural adaptation programme, QOLIE-31 has been translated into many languages, including Spanish (12), German (13), Hungarian (14), Georgian (15), French (16), Serbian (17), Persian (18) and Turkish (19).

Although many instruments have been developed for evaluation of QOL $(20,21)$, none has been validated in Morocco until now. The availability of such an inventory in the Arabic language, according to the cultural specificities of Morocco, is essential for conducting future studies about QOL in people with epilepsy. The objective of this study was to translate, adapt and validate the Moroccan Arabic version of QOLIE-13 (MA-QOLIE-31) to evaluate HRQOL predictors in Moroccan people with epilepsy.

\section{Methods}

\section{Characteristics of the original version of QOLIE-31}

QOLIE-31 is the shortened form of QOLIE-89. QOLIE-31 is a specific instrument for rapid evaluation of the main 
QOL domains in adults with epilepsy. QOLIE-31 is a 31item questionnaire organized in 7 subscales: seizure worry (SW), overall QOL (OQL), emotional well-being (EWB), energy and fatigue (EF), cognitive function $(\mathrm{CF})$, medication effects (ME) and social functioning (SF). We did not remove the driving question from MA-QOLIE-31, even though most participants did not have access to motor vehicles.

\section{Translation and cultural adaptation of QOLIE-31}

We translated the QOLIE-31 into Moroccan Arabic language. We followed the published guidelines for crosscultural adaptation of HRQOL measurements $(22,23)$. Two bilingual translators initially translated the questions in the original version of QOLIE-31 into Moroccan Arabic (Appendices 1 and 2). Then we submitted the translated version to a committee of neurologists and epidemiologists, to obtain the initial Moroccan Arabic version. We applied MA-QOLIE-31 to volunteers with epilepsy that agreed to participate and give their opinion. Two examiners noted the comments and suggestions of the participants. The second Moroccan Arabic version was compiled after this initial assessment. Two translators with a good knowledge in English, not familiar with QOLIE-31, performed the subsequent back translation into English. The committee of professionals and translators performed a comparison with the original version to check the differences, and reviewed and adjusted the translation accordingly to obtain the final MA-QOLIE-31.

\section{Patient recruitment}

Between December 2016 and July 2018, adult outpatients who were followed up at an epilepsy centre over the previous month while living in the Fez-Meknes Region were included in the study. The sample size was defined according to a Streiner curve (24), for an intraclass correlation coefficient (ICC) of 0.70 and a precision of \pm 0.10 . Patients were eligible if they were aged $\geq 18$ years, had epilepsy and spoke Moroccan Arabic. Individuals with intellectual deficiency and psychiatric disorders responsible for communication difficulty were excluded. Ethical approval (203/18) was obtained from the ethics committees in the University Hospital Center Hassan II in Fez and all the participants were informed of the conditions related to the study and gave their informed consent.

\section{Data collection}

As almost patients in our sample were illiterate, 2 interviewers administered the questionnaire. Their task was to read out the questions and mark the chosen answers for this category of patients without providing any input. They administered MA-QOLIE-31 to all participants. We randomly defined the order of interviewers. They re-administered the same questionnaire after 7 days to assess reproducibility. Participants provided sociodemographic (age, sex, monthly income and physical activity) and clinical data (average follow-up, type of epilepsy, frequency of seizures, treatment resistance, age at first seizure and therapeutic support).

\section{Scoring}

MA-QOLIE-31 included 7 multi-item scales: SW (5 items), EWB (5 items), EF (4 items), SF (5 items), CF (6 items), ME ( 3 items) and OQL ( 2 items). The scoring procedure first converted the numerical values to point scores of 0-100, with higher converted scores reflecting better QOL. Next, we entered the converted score for each item in a column labelled "Subtotal". Then, we summed the subtotal scores for each scale and entered these values in places marked "Total". Finally, we divided each Total by the number of items that the participant answered within each scale to obtain the "Final Score". An overall score was obtained using a weighted mean of the multi-item scale scores. We calculated the global and subscale scores (range 0-100) according to the Scoring Manual of QOLIE-31 (version 1.0) (25), with higher scores indicating better QOL.

\section{Statistical analysis}

Descriptive statistics were generated to evaluate the scores' distribution (i.e. mean, range, floor, and ceiling effects). For each scale of MA-QOLIE-31, if $>20 \%$ of the participants reported lowest or highest possible score, the floor or ceiling effects existed. The reliability of the multi-item scales was assessed by the Cronbach $\alpha$ coefficient. A value of $\geq 0.70$ was considered as adequate (26). The test-retest reliability and interobserver reliability were estimated by calculating the ICC for each of the score components of MA-QOLIE-31. Multitrait scaling analysis was used to examine item convergence and item discrimination. Evidence of item convergence was defined as a correlation of $\geq 0.40$ between an item and its own scale. Item discrimination was satisfactory if each item had a substantially higher correlation with its hypothesized scale than with scales measuring other concepts. The data were analysed using SPSS 17.0.

\section{Results}

\section{Sociodemographic and clinical data}

We administered the questionnaire to 120 participants. Two patients did not respond to the retest and they were automatically excluded. We analysed 118 questionnaires. The median age of onset of epilepsy was 32.70 (standard deviation 13.1) years with a mean epilepsy duration of 15.14 (10.41) years. Table 1 shows the sociodemographic characteristics of the participants. The mean time to complete the questionnaire was 13.5 minutes. All items showed no missing responses.

\section{Central tendency}

The central tendency is used to identify the central position for a set of data. Table 2 summarizes the data on the central tendency and variability of MA-QOLIE-31. The scores for different scales ranged from 41.3 to 66.8 . The EF scale had the lowest score (median 40) and the ME 


\begin{tabular}{|c|c|}
\hline Characteristics & n (\%) \\
\hline \multicolumn{2}{|l|}{ Sex } \\
\hline Female & $55(46.61)$ \\
\hline Male & $63(53.38)$ \\
\hline \multicolumn{2}{|l|}{ Type of epilepsy } \\
\hline Generalized & $65(55.08)$ \\
\hline Focal & $53(44.91)$ \\
\hline \multicolumn{2}{|l|}{ Refractory to antiepileptic drugs } \\
\hline Yes & $38(32.20)$ \\
\hline No & $80(67.79)$ \\
\hline Duration of epilepsy, yr, mean (SD) & $15.14(10.41)$ \\
\hline \multicolumn{2}{|l|}{ No. of treatments } \\
\hline 1 & $47(39.83)$ \\
\hline 2 & $43(36.44)$ \\
\hline 3 & $24(20.33)$ \\
\hline 4 & $4(3.38)$ \\
\hline \multicolumn{2}{|l|}{ No. of seizures per month } \\
\hline 0 & $40(33.89)$ \\
\hline$>30$ & 0 \\
\hline $1-5$ & $55(46.61)$ \\
\hline $5-10$ & $1(0.84)$ \\
\hline $10-15$ & $12(10.16)$ \\
\hline $15-20$ & $10(8.47)$ \\
\hline \multicolumn{2}{|l|}{ Monthly income (US dollars) } \\
\hline$<100$ & $80(67.79)$ \\
\hline $100-200$ & $19(16.10)$ \\
\hline $200-300$ & $1(0.84)$ \\
\hline $300-400$ & $3(2.54)$ \\
\hline$>500$ & $15(12.71)$ \\
\hline \multicolumn{2}{|l|}{ Sports activity (days per week) } \\
\hline 0 & $86(72.88)$ \\
\hline 1 & $24(20.33)$ \\
\hline 2 & $4(3.38)$ \\
\hline 3 & $3(2.54)$ \\
\hline$>3$ & $1(0.84)$ \\
\hline
\end{tabular}

scale had the highest score (88.9). The highest ceiling effect was shown in the ME scale.

\section{Reliability}

Table 3 shows the reliability of MA-QOLIE-31. The Cronbach $\alpha$ coefficient ranged from 0.98 to 0.99 . This coefficient was high for the entire questionnaire (0.993). The ICC between 2 interviewers ranged from 0.96 for the OQL to 0.99 for ME. We collected test-retest data from 69 patients to whom the questionnaire was administered twice (during the baseline visit and 7 days later). The test-retest reliability was assessed using ICC, which ranged from 0.93 for the OQL to 0.98 for the CF.

\section{Validity}

The study committee validated the appearance and content of MA-QOLIE- 31. Table 4 shows the results of subscales analysis. All items exceeded the 0.4 criteria for convergent validity on all subscales. The CF subscale exhibited $100 \%$ item-convergence (r: $0.57-0.85$ ) and $91.66 \%$ item-discrimination (r: 0.003-0.73).

\section{Discussion}

QOL instruments have seldom been used in clinical practice to assess patients with epilepsy in Morocco. We still rely on seizure frequency to measure the impact of epilepsy on HRQOL. The objective of the present study was to provide a translated and adapted Moroccan Arabic version of QOLIE-31 to study 118 people with epilepsy.

The acceptability of MA-QOLIE-13 was high, as patients had to fill out the questionnaire in Moroccan Arabic with the interviewer. Also, the psychometric properties and reproducibility were satisfactory and similar to studies in other countries $(9,13,16)$. Our results were similar to those in the USA (9), Germany (13), Spain (12) and other countries (Table 5). Surprisingly, our global and individual scores were higher than those found in previous studies. The expectations related to convergent validation disclosed high correlations with the different domains of MA-QOLIE-31. Our results confirm the reliability and validity of MA-QOLIE-13, but the higher values may be explained by the short intervening period between test and retest in comparison with other studies.

The HRQOL among our population may have been influenced by seizure frequency, number of medications and economic conditions. First, the frequency of seizures is still considered the cornerstone to measure QOL in

\begin{tabular}{|c|c|c|c|c|c|c|}
\hline Subscales & No. of items & Mean & Median & SD & Floor effect $(\%)$ & Ceiling effect (\%) \\
\hline EWB & 5 & 45.6 & 52.0 & 26.8 & 7.7 & 0.9 \\
\hline SF & 5 & 52.4 & 50.0 & 30.3 & 5.1 & 6.8 \\
\hline $\mathrm{EF}$ & 4 & 41.3 & 40.0 & 25.4 & 9.4 & 0.9 \\
\hline $\mathrm{CF}$ & 6 & 47.6 & 43.9 & 28.3 & 4.3 & 4.3 \\
\hline SW & 5 & 51.0 & 50.0 & 36.9 & 12.0 & 15.4 \\
\hline $\mathrm{ME}$ & 3 & 66.8 & 88.9 & 39.5 & 16.2 & 48.7 \\
\hline OQL & 2 & 48.9 & 50.0 & 25.4 & 7.7 & 0.9 \\
\hline
\end{tabular}

$\mathrm{CF}=$ cognitive function; $\mathrm{EF}=$ energy and fatigue; $\mathrm{EWB}=$ emotional well-being; $M E=$ medication effects; $\mathrm{OQL}=$ overall quality of life; $\mathrm{QOLIE}-31=\mathrm{Quality}$ of Life Inventory in Epilepsy; $\mathrm{SD}=$ standard deviation; $S F=$ social functioning; $S W=$ seizure worry. 


\begin{tabular}{lccc}
\hline $\begin{array}{l}\text { Table } 3 \text { Internal consistency and reliability of the QOLIE-31 } \\
\text { Subscales }\end{array}$ & $\begin{array}{c}\text { Interobserver } \\
\text { Cronbach } \alpha \text { coefficient }\end{array}$ & $\begin{array}{c}\text { Test-retest } \\
\text { ICC (95\% CI) }\end{array}$ \\
\hline SW & 0.99 & $0.99(0.98-0.99)$ & $0.98(0.97-0.99)$ \\
OQL & 0.98 & $0.96(0.95-0.97)$ & $0.93(0.89-0.95)$ \\
EWB & 0.99 & $0.98(0.97-0.98)$ & $0.96(0.94-0.98)$ \\
EF & 0.98 & $0.97(0.96-0.98)$ & $0.96(0.94-0.98)$ \\
CF & 0.99 & $0.98(0.98-0.99)$ & $0.98(0.97-0.99)$ \\
ME & 0.99 & $0.99(0.98-0.99)$ & $0.98(0.96-0.98)$ \\
SF & 0.99 & $0.99(0.98-0.99)$ & $0.98(0.97-0.98)$ \\
\hline
\end{tabular}

$\mathrm{CF}=$ cognitive function; $\mathrm{CI}=$ confidence interval; $\mathrm{EF}=$ energy and fatigue; $\mathrm{EWB}=$ emotional well-being; $\mathrm{ICC}=$ intraclass correlation coefficient; $M E=$ medication effects; $\mathrm{OQL}=$ overall quality of life; QOLIE-31 = Quality of Life Inventory in Epilepsy; SD = standard deviation; SF = social functioning; SW = seizure worry.

Moroccan patients with epilepsy. Accordingly, only patients with drug-resistant epilepsy were considered to have poor QOL. Second, patients taking more than one drug were thought to have a similar condition with a lower QOL, although there is no local study to support these views. The evaluation of risk factors for poor QOL was not the aim of the present study; however, the validity of MA-QOLIE-31 will be the main basis for conducting future studies. Finally, the global score (Table 5), was lower than that in the original American (9), French (16) and Spanish (12) studies. The global score for MA-QOLIE-13 was similar to that in middle- and lowincome countries (27). The Moroccan scores were similar to those in Bhutan (28). The MA-QOLIE-31 scores also varied significantly with monthly income. People with income $<100$ US dollars had lower scores than those with an income $>500$ US dollars. A Hungarian study showed better QOL among active people than disabled patients receiving a disability pension (14).

The EF domain had the lowest mean overall score in MA-QOLIE-31. The large proportion of patients with focal drug-resistant epilepsy may explain this result (29). They had high seizure frequency and were taking $>1$ antiepileptic drug. The ME domain had the highest mean overall QOL score. The Moroccan population,

Table 4. Convergence and discrimination of the QOLIE-31 subscales

\begin{tabular}{lcc} 
Subscales & $\begin{array}{c}\text { Convergence } \\
\text { (r, \% success) }\end{array}$ & $\begin{array}{c}\text { Discrimination } \\
\text { (r, \% success) }\end{array}$ \\
\hline SW & $0.70-0.90,100$ & $0.10-0.42,100$ \\
OQL & $0.89-0.91,100$ & $0.06-0.64,100$ \\
EWB & $0.76-0.92,100$ & $0.04-0.69,100$ \\
EF & $0.75-0.87,100$ & $0.02-0.69,100$ \\
CF & $0.57-0.85,100$ & $0.003-0.73,91.66$ \\
ME & $0.82-0.96,100$ & $0.006-0.41,100$ \\
SF & $0.69-0.81,100$ & $0.14-0.64,100$ \\
\hline
\end{tabular}

$C F=$ cognitive function; $E F=$ energy and fatigue; $E W B=$ emotional well-being; $M E=$ medication effects; OQL = overall quality of life; QOLIE-31 $=$ Quality of Life Inventory in Epilepsy; $S D=$ standard deviation; $S F=$ social functioning; $S W=$ seizure worry. especially people with low income, may have a cultural pharmacophilia that explains the high satisfaction reached by medication intake. Access to medical care remains difficult in our context as in low- and middleincome countries $(30,31)$.

The scores for SF were moderate, even though the population did not undertake sufficient physical activity. The majority did not drive, although they did not have social limitations. They should have a good QOL with family and close friends as found in Moroccan culture.

The Cronbach $\alpha$ coefficients for overall scores in the present study were similar to those in American (9), German (15) and Spanish (14) studies. Cronbach $\alpha$ coefficients for individual items were also similar to those previously found in other languages. The discriminatory validation was satisfactory and in agreement with other studies. Expectations related to convergent validation disclosed high correlations with the different domains of MA-QOLIE-31. The results confirm the reliability and validation of the Moroccan Arabic translation of QOLIE-13 and suggest that differences in item and scale scores are not attributable to inadequate translation.

The short period between the test and retest may be a limitation of this study and might explain in part the high values of the coefficients obtained.

\section{Conclusion}

We translated and validated a Moroccan Arabic language version of the international multi-item epilepsy inventory QOLIE-31), according to the international recommendations. The mean overall score for QOL in 118 Moroccan patients with epilepsy was similar to that in low- and middle-income countries. Nevertheless, the predictors of QOL in the Moroccan context are not yet well known but further studies should answer these pending questions. The availability of such a validated QOL instrument related to epilepsy will facilitate larger studies in Morocco and other Arabic-speaking countries. 


\begin{tabular}{|c|c|c|c|c|c|c|c|}
\hline & Moroccan Arabic & French & $\begin{array}{l}\text { American } \\
\text { English }\end{array}$ & Spanish & German & Hungarian & Georgian \\
\hline SW & $51.0(36.8)$ & $58.7(30.1)$ & $58(26)$ & $51.5(29.7)$ & N/A & $54.0(28.5)$ & N/A \\
\hline OQL & $48.8(25.4)$ & $64.0(21.1)$ & $67(18)$ & $68.3(16.9)$ & N/A & $55.5(19.3)$ & $\mathrm{N} / \mathrm{A}$ \\
\hline EWB & $45.6(26.7)$ & $57.6(20.6)$ & $67(19)$ & $61.8(19.1)$ & $\mathrm{N} / \mathrm{A}$ & $58.3(18.5)$ & $\mathrm{N} / \mathrm{A}$ \\
\hline $\mathrm{EF}$ & $41.2(25.3)$ & $51.7(19.8)$ & $55(12)$ & $60.9(20.7)$ & $\mathrm{N} / \mathrm{A}$ & $49.7(17.7)$ & N/A \\
\hline $\mathrm{CF}$ & $47.5(28.3)$ & $61.7(25.4)$ & $60(23)$ & $60.3(23.8)$ & $\mathrm{N} / \mathrm{A}$ & $59.3(19.5)$ & N/A \\
\hline ME & $66.8(39.4)$ & $65.5(30.1)$ & $55(31)$ & $60.3(29.1)$ & N/A & $57.4(31.1)$ & N/A \\
\hline SF & $52.4(30.2)$ & $69.4(26.4)$ & $67(21)$ & $66.4(28.0)$ & N/A & $56.8(23.6)$ & N/A \\
\hline Global score & $68.0(22.1)$ & $61.9(19.0)$ & $63(16)$ & $61.7(17.3)$ & N/A & $\mathrm{N} / \mathrm{A}$ & $\mathrm{N} / \mathrm{A}$ \\
\hline \multicolumn{8}{|c|}{ Cronbach $\alpha$} \\
\hline Global score & 0.99 & 0.89 & 0.93 & 0.92 & 0.94 & $\mathrm{~N} / \mathrm{A}$ & 0.77 \\
\hline Subscale range & $0.98-0.99$ & $0.71-0.86$ & $0.77-0.85$ & $0.55-0.83$ & $0.76-0.90$ & $\mathrm{~N} / \mathrm{A}$ & $0.71-0.82$ \\
\hline \multicolumn{8}{|c|}{ Test-retest } \\
\hline Global score & 0.97 & 0.86 & 0.89 & 0.90 & 0.79 & N/A & N/A \\
\hline Sub-scale range & $0.93-0.98$ & $0.82-0.85$ & $0.64-0.89$ & $0.62-0.84$ & $0.59-0.78$ & $\mathrm{~N} / \mathrm{A}$ & $\mathrm{N} / \mathrm{A}$ \\
\hline
\end{tabular}

Results are mean (standard deviation). $\mathrm{CF}=$ cognitive function; $\mathrm{EF}=$ energy and fatigue; $\mathrm{EWB}=$ emotional well-being; $\mathrm{ME}=$ medication effects; $\mathrm{NA}=$ not applicable; $\mathrm{OQL}=$ overall quality of life; QOLIE-31 = Quality of Life Inventory in Epilepsy; SD = standard deviation; SF = social functioning; SW = seizure worry.

\section{Acknowledgement}

We thank Joyce A. Cramer, the author of the QOLIE-31, for her agreement and for providing the original version of the QOLIE-31. We thank El Hachimi M, Ennefida R and Benbrahim F for their help in this work; also, we thank Aalouane R, Hajjioui A, Tachfouti N and Kaplan P for their critical lecture of the manuscript.

Funding: None.

Competing interests: None declared.

\section{Version arabe marocaine de l'inventaire de la qualité de vie chez les patients épileptiques (QOLIE-31) : traduction, adaptation culturelle et validation psychométrique Résumé}

Contexte : La réalisation d'études sur la qualité de vie liée à la santé (QVLS) chez les personnes atteintes d'épilepsie dans les pays à revenu faible et intermédiaire est un motif de préoccupation de plus en plus important, car la plupart des données proviennent de pays à revenu élevé en Amérique du Nord et en Europe.

Objectifs : Traduire, adapter et valider la version arabe marocaine de l'inventaire de la qualité de vie chez les patients épileptiques (QOLIE-31) afin d'évaluer les facteurs prédictifs de la qualité de vie liée à la santé dans la population marocaine épileptique.

Méthodes : L'adaptation et la validation de l'inventaire QOLIE-31 ont été réalisées en juillet 2018 auprès de 118 patients épileptiques de la région de Fès-Meknès. Le test a été traduit, adapté et validé en arabe selon les recommandations de Streiner et Norman (2008). L'acceptabilité, la fiabilité, la tendance centrale et la validité du QOLIE-31 ont été évaluées.

Résultats : L'acceptabilité et la reproductibilité sont satisfaisantes et la cohérence interne est forte ( $\alpha$ de Cronbach $=$ 0,993). Le score global moyen (écart type) de la qualité de vie dans la version marocaine du QOLIE-31 était de $68(22,16)$. Les scores des sous-échelles étaient $51(36,88)$ pour les crises convulsives, $48,86(25,44)$ pour la qualité de vie globale, $45,60(26,73)$ pour le bien-être, 41,28 (25,37) pour l'énergie et la fatigue, $47,55(28,33)$ pour la fonction cognitive, $66,83(39,49)$ pour les effets médicamenteux et $52,44(30,26)$ pour le fonctionnement social.

Conclusions : Le score global de la qualité de vie des patients marocains épileptiques est similaire à celui des patients des pays à revenu faible et intermédiaire. La version marocaine du QOLIE-31 permettra de réaliser davantage d'études sur la qualité de vie liée à la santé au Maroc ainsi que dans les pays arabophones. 


\section{النسخة المغربية العربية لاستحارة تقييم جودة الحياة للمصابين بالصرع : الترجمة، والمواءمة الثقافية، والمصادقة على القياسات النفسية المغرية العربية}

$$
\text { مريم علمي مروني، عبد الكريم جناتي ادريسي، عبد العزيز لمقدم، . فيلانكيبو كافا أ. س، سميرة الفقير، زهير سويرتي }
$$

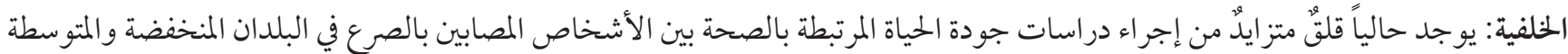

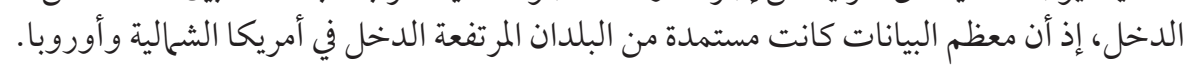

الأهداف: هدفت هذه الدراسة إلى ترجمة النسخة المغربية العربية لاستحارة تقييم جودة الحياة للمصابين بالصرع ومواءمتها والتحقق من صحتها

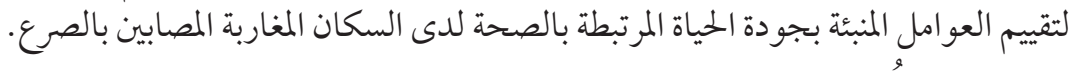

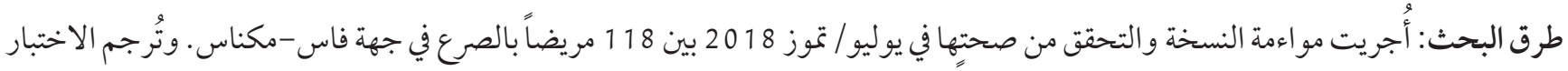

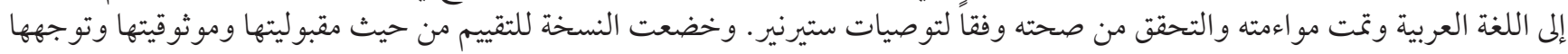
المركزي و صحتها.

النتائج: كان مستوى المقبولية والنناتج مرضياً، وكان الاتساق الداخلي قوياً (معامل ألفا كرونباخ =

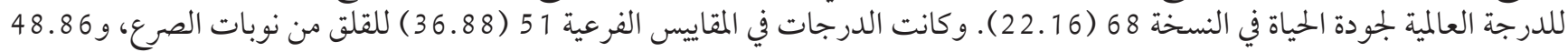

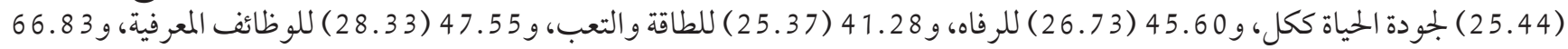

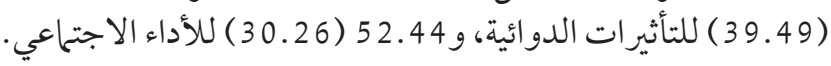

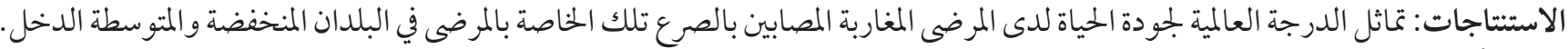

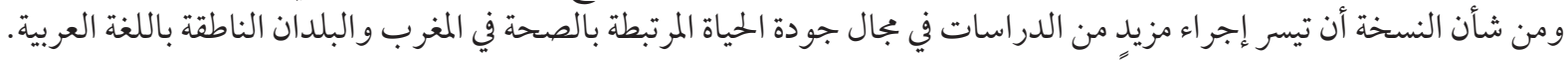

\section{References}

1. Taylor RS, Sander JW, Taylor RJ, Baker GA. Predictors of health-related quality of life and costs in adults with epilepsy: a systematic review. Epilepsia. 2011 Dec;52(12):2168-80. http://dx.doi.org/10.1111/j.1528-1167.2011.03213.x PMID:21883177

2. Cano-López I, Hampel KG, Garcés M, Villanueva V, González-Bono E. Quality of life in drug-resistant epilepsy: relationships with negative affectivity, memory, somatic symptoms and social support. J Psychosom Res. 2018 Nov;114:31-7. http://dx.doi. org/10.1016/j.jpsychores.2018.09.001 PMID:30314576

3. Ferreira MCG, Tura LFR, Silva RC da, Ferreira M de A. Social representations of older adults regarding quality of life. Rev Bras Enferm. 2017 Jul-Aug;70(4):806-13. http://dx.doi.org/10.1590/0034-7167-2017-0097 PMID:28793112

4. Yogarajah M, Mula M. Social cognition, psychiatric comorbidities, and quality of life in adults with epilepsy. Epilepsy Behav 2019 Nov;100(Pt B):106321. http://dx.doi.org/10.1016/j.yebeh.2019.05.017 PMID:31253548

5. L Devlin A, Odell M, L Charlton J, Koppel S. Epilepsy and driving: current status of research. Epilepsy Res. 2012 Dec;102(3):135-52. http://dx.doi.org/10.1016/j.eplepsyres.2012.08.003 PMID:22981339

6. Wo MCM, Lim KS, Choo WY, Tan CT. Factors affecting the employability in people with epilepsy. Epilepsy Res. 2016 Dec;128:611. http://dx.doi.org/10.1016/j.eplepsyres.2016.10.003 PMID:27792885

7. Wo MCM, Lim KS, Choo WY, Tan CT. Employability in people with epilepsy: a systematic review. Epilepsy Res. 2015 Oct;116:6778. http://dx.doi.org/10.1016/j.eplepsyres.2015.06.016 PMID:26354169

8. Janati Idrissi A, Lamkaddem A, Boujraf S, Souirti Z. Awareness and attitudes toward persons with epilepsy among teachers: a Moroccan study. Epilepsy Behav. 2020 Jan;102:106633. https://doi.org/10.1016/j.yebeh.2019.106633

9. Cramer JA, Perrine K, Devinsky O, Bryant-Comstock L, Meador K, Hermann B. Development and cross-cultural translations of a 31-item quality of life in epilepsy inventory. Epilepsia. 1998 Jan;39(1):81-8. http://dx.doi.org/10.1111/j.1528-1157.1998.tbo1278.x PMID:9578017

10. Birbeck GL, Hays RD, Cui X, Vickrey BG. Seizure reduction and quality of life improvements in people with epilepsy. Epilepsia. 2002 May;43(5):535-8. http://dx.doi.org/10.1046/j.1528-1157.2002.32201.x PMID:12027916

11. Wiebe S, Matijevic S, Eliasziw M, Derry PA. Clinically important change in quality of life in epilepsy. J Neurol Neurosurg Psychiatry. 2002 Aug;73(2):116-20. http://dx.doi.org/10.1136/jnnp.73.2.116 PMID:12122166

12. Torres X, Arroyo S, Araya S, de Pablo J. The Spanish Version of the Quality-of-Life in Epilepsy Inventory (QOLIE-31): translation, validity, and reliability. Epilepsia. 1999 Sep;40(9):1299-304. http://dx.doi.org/10.1111/j.1528-1157.1999.tboo861.x PMID:10487195 
13 May TW, Pfäfflin M, Cramer JA. Psychometric properties of the German translation of the QOLIE-31. Epilepsy Behav. 2001 Apr;2(2):106-14. http://dx.doi.org/10.1006/ebeh.2001.0170 PMID:12609192

14. Lám J, Rózsavölgyi M, Soós G, Vincze Z, Rajna P. Quality of life of patients with epilepsy (Hungarian survey). Seizure. 2001 Mar;10(2):100-6. https://doi.org/10.1053/seiz.2000.0461

15. Djibuti M, Shakarishvili R. Influence of clinical, demographic, and socioeconomic variables on quality of life in patients with epilepsy: findings from Georgian study. J Neurol Neurosurg Psychiatry. 2003 May;74(5):570-3. http://dx.doi.org/10.1136/ jnnp.74.5.570 PMID:12700294

16. Picot M-C, Crespel A, Daurès J-P, Baldy-Moulinier M, El Hasnaoui A. Psychometric validation of the French version of the quality of life in epilepsy inventory (QOLIE-31): comparison with a generic health-related quality of life questionnaire. Epileptic Disord. 2004 Dec;6(4):275-85. PMID:15634625

17. Martinović Ž, Milovanović M, Tošković O, Jovanović M, Buder N, Simonović P, et al. Psychometric evaluation of the Serbian version of the Quality of Life in Epilepsy Inventory-31 (QOLIE-31). Seizure. 2010 Oct;19(8):517-24. http://dx.doi.org/10.1016/j. seizure.2010.07.012

18. Mohammadi N, Kian S, Davoudi F, Nia SMAA, Nojomi M. Psychometric evaluation of the Persian version of the quality of life in epilepsy inventory-31. Iran J Neurol. 2013;12(4):144-8. PMID:24250924

19. Mollaoğlu M, Durna Z, Bolayir E. Validity and reliability of the Quality of Life in Epilepsy Inventory (QOLIE-31) for Turkey. Noro Psikiyatri Arsivi. 2015 Sep;52(3):289-95. http://dx.doi.org/10.5152/npa.2015.8727 PMID:28360726

20. Baker GA, Smith DF, Dewey M, Jacoby A, Chadwick DW. The initial development of a health-related quality of life model as an outcome measure in epilepsy. Epilepsy Res. 1993 Sep;16(1):65-81. http://dx.doi.org/10.1016/0920-1211(93)90041-5 PMID:8243441

21. Vickrey BG, Hays RD, Graber J, Rausch R, Engel J, Brook RH. A health-related quality of life instrument for patients evaluated for epilepsy surgery. Med Care. 1992 Apr;30(4):299-319. http://dx.doi.org/10.1097/00005650-199204000-00002 PMID:1556879

22. Beaton DE, Bombardier C, Guillemin F, Ferraz MB. Guidelines for the process of cross-cultural adaptation of self-report measures. Spine. 2000 Dec 15;25(24):3186-91. http://dx.doi.org/10.1097/00007632-200012150-00014 PMID:11124735

23. Guillemin F, Bombardier C, Beaton D. Cross-cultural adaptation of health-related quality of life measures: literature review and proposed guidelines. J Clin Epidemiol. 1993 Dec;46(12):1417-32. http://dx.doi.org/10.1016/0895-4356(93)90142-n PMID:8263569

24. Streiner DL, Norman GR. Health measurement scales: a practical guide to their development and use. Oxford University Press; 2008.

25. Quality of Life in Epilepsy Inventory (QOLIE-89 and QOLIE-31) [website]. RAND Health Care (https://www.rand.org/health-care/ surveys_tools/qolie.html, accessed 24 September 2020).

26. Cronbach LJ. Coefficient alpha and the internal structure of tests. Psychometrika. 1951;16(3):297-334. https://doi.org/10.1007/ BF02310555

27. Saadi A, Patenaude B, Mateen FJ. Quality of life in epilepsy-31 inventory (QOLIE-31) scores: A global comparison. Epilepsy Behav. 2016 Dec;65:13-7. http://dx.doi.org/10.1016/j.yebeh.2016.09.032 PMID:27838562

28. Saadi A, Patenaude B, Nirola DK, Deki S, Tshering L, Clark S, et al. Quality of life in epilepsy in Bhutan. Seizure. 2016 Jul;39:44-8. http://dx.doi.org/10.1016/j.seizure.2016.05.001 PMID:27257785

29. Puri I, Dash D, Padma MV, Tripathi M. Quality of life and its determinants in adult drug refractory epilepsy patients who were not candidates for epilepsy surgery: a correlational study. J Epilepsy Res. 2018 Dec 31;8(2):81-6. http://dx.doi.org/10.14581/jer.18013 PMID:30809501

30. Kotsopoulos IAW, Evers SMAA, Ament AJHA, Kessels FGH, de Krom MCTFM, Twellaar M, et al. The costs of epilepsy in three different populations of patients with epilepsy. Epilepsy Res. 2003 May;54(2-3):131-40. https://doi.org/10.1016/So920$1211(03) 00062-7$

31. Wijnen BFM, Schat SL, de Kinderen RJA, Colon AJ, Ossenblok PPW, Evers SMAA. Burden of disease of people with epilepsy during an optimized diagnostic trajectory: costs and quality of life. Epilepsy Res. 2018 Oct;146:87-93. http://dx.doi.org/10.1016/j. eplepsyres.2018.07.024 PMID:30086483 